Article

\title{
Applications of a Novel Method of Ecosystem Services Assessment into Local Policy Making in the River Blackwater Estuary, Ireland
}

\author{
David Doran ${ }^{1, *}$ and Tim O'Higgins ${ }^{2}$ \\ 1 Department of Governance and Technology for Sustainability, CSTM, University of Twente, \\ 7522 NB Enschede, The Netherlands \\ 2 MaREI, Environmental Research Institute, Beauford Building, University College Cork, \\ County Cork, Ireland; tim.ohiggins@ucc.ie \\ * Correspondence: d.doran@alumnus.utwente.nl
}

Received: 5 October 2020; Accepted: 28 October 2020; Published: 30 October 2020

\begin{abstract}
This article describes a method to allow for the incorporation of ecosystem services (ES) into policy, applied to the case of the River Blackwater Estuary, County Cork. The concept of ES has become mainstreamed into many country's policies worldwide. However, practical applications of ES assessment are still far from mainstream. This paper aims to assess ES in three sites to inform site selection for conservation and enhancement measures. First, ES likely to occur in the proposed development sites were identified based on literature review, interviews and expert judgement. Second an assessment methodology involving a public survey was developed and applied. Finally, the results of the assessment were aggregated based on the use level for cultural services and the on-site area for regulating and provisioning services; the results were normalised and synthesised to produce a replicable basis for comparison across the sites. The assessment demonstrated a low-cost, practical methodology for incorporating ES into local decision-making. Regulating and cultural services were most valued at the three sites, with limited levels of provisioning services being provided. While pollination (a supporting service/intermediate regulating service) received highest overall scores, a suite of cultural services was also highly valued. The survey suggested that public engagement with ES concepts may be hampered by technical jargon, such as that employed by the Common International Classification of Ecosystem Services (CICES), and also illustrated that in this case the public engaged better with the intermediate or supporting ES of pollination than other final services that provided benefits directly to them. The implications of these findings for future applications and the assessment methodology are discussed.
\end{abstract}

Keywords: ecosystem services; policy recommendations; stakeholder participation

\section{Introduction}

Estuaries are often desirable locations to live and work, with 22 of the 32 largest cities in the world located on estuaries. These ecosystems, with their unique plant and animal life, provide a variety of services that foster human well-being [1]. Ecosystem services (ES) are defined as the benefits humans gain from ecosystems [2]. Fundamentally, all human activities are completely dependent on nature and the ES it provides, and there are many different pathways by which aspects of nature directly or indirectly impact human welfare [3].

Costanza et al. (1997) offered a crude estimate of the value of ES globally [4], and the concept of ES gained further traction through the Millennium Ecosystem Assessment, which presented the first classification of ES, recognising supporting, cultural and provisioning services [2]. Today, many institutional initiatives and larger-scale projects have been established to assist in the incorporation 
of ES into policy [5], and much research and many attempts at incorporation of ES into policy have been undertaken, resulting in the refinement and improvement of the classification (e.g., [6,7]) as well as the applied methodologies [8]. However, routine practical application is still limited, even after almost 25 years of dedicated research. It is worth noting that the language used in the main ES classifications schemes has remained substantially unchanged since the Millennium Ecosystem Assessment [2]. The Common International Classification for Ecosystem Services (CICES) [7], has become the emerging international standard for classification of ES. This considers both biotic and abiotic services, and its approach is firmly rooted in the systematic classification systems of the natural science tradition, with various categories and subcategories identified for each service type.

The study of ES is by its nature multi-disciplinary. Ecologists study the functions of the natural systems, their processes and rates, while economists can measure changes in human welfare. While some integrated models of ecosystem service supply and demand do exist (e.g., [9-11]), these are complex to use and are not widely operationalised. In practice many studies of ES are limited to either the supply or demand side; for example, Haines-Young and Potschin (2018) [7] used habitat maps and the CICES system to estimate supply of European ES from terrestrial habitats. Several other authors (principally natural scientists) have focussed exclusively on assessment of the ecosystem service supply side only $[12,13]$. These authors stressed the importance of capturing the complexity of ecosystem service flows from ecosystem processes and the impacts of human activities upon these flows. Yet, the demand-side consideration for ES is critical. Fisher et al. (2009) [14] state clearly, "if there are no human beneficiaries it is not a service". These authors also advert to the importance of complementary capital connecting services with final users. This beneficiary-centric (demand side) approach is exemplified by the Final Ecosystem Goods and Services approach [15], where services are identified by reference to the beneficiary rather than to the ecosystem component that supplies them. When considering the demand side of ES and valuation, double counting is an important consideration. Under such circumstances, intermediate and supporting services should be omitted from the analysis, since they are not experienced directly by the beneficiary [6]. For example, pollination can lead to the provisioning of wild plants, which can be directly consumed by humans. In this case, pollination is an intermediate (or supporting) ES, while the provisioning of wild plants, for nutritional purposes for example, is a final ecosystem service [14].

What and how we choose to measure ES is key to their successful use as an instrument to effect policy. Yet, the competing disciplinary backgrounds of ecological and social sciences have adopted differing approaches toward the operationalisation of ecosystem service concepts, and while considerable progress has been made in both areas, the practical use of ES as a means for analysing and solving environmental management problems is still very far from common practice.

Despite indications that estuarine environments are rich in the supply of ES [16], a lack of focus on ES in policy is a major reason for the decline of ecosystems and ES worldwide [16,17]. Schmidt and Seppelt (2018) [18] identified five stages for the incorporation of ES into decision-making: “(i) quantitatively recognise nature's value, (ii) develop prioritisation schemes based on ES valuation, (iii) sensitive stakeholder engagement, (iv) support information access and capacity building to establish ES-based decision-making and (v) consider long-term returns of interventions in ES". This study deals with elements in the first four of these stages.

In this study, the CICES classification system was adapted to develop a public survey instrument for the semi-quantitative assessment of ES and applied to prioritise potential development in three sites in River Blackwater Estuary by engaging with stakeholders and the public. The method is intended to build capacity in local ES decision-making. The estuary is one of six regions within Europe taking part in the Delta Lady project by Interreg Europe (see https://www.interregeurope.eu/deltalady/). The aim of the Delta Lady project is to improve the regional policy instruments, which facilitates the use of ES as a tool to strengthen regional economies using cross-regional learnings. The paper aims to illustrate the development and application of a low-cost reproducible method for the assessment of ES, which could be useful learning for other partners on the project looking to perform an ES assessment. 
Learnings from other partners were also applied throughout this study. First the method is described, and second, the results of the application are presented to illustrate the differences in supply and demand for ES at the case study sites. Some observations on the accessibility of ecosystem service concepts are identified, and recommendations for the improved integration of ES into decision-making are provided.

\section{Materials and Methods}

\subsection{Study Area}

The River Blackwater estuary is located in the southwest of the Republic of Ireland. The estuary $\left(51^{\circ} 97^{\prime} \mathrm{N}, 7^{\circ} 84^{\prime} \mathrm{W}\right)$ creates a natural boundary between counties Cork and Waterford, with Youghal, County Cork (population approximately 8000 people) sitting on its west bank. The estuary is highly valued for the natural habitats and aerial, terrestrial and aquatic species that inhabit the area, being a Ramsar site, a Special Protected Area and a Special Area of Conservation (Figure 1) [19-21]. The estuary is shallow, with an average depth of $4.2 \mathrm{~m}$, and is classified as mesotidal (tidal range of $3.6 \mathrm{~m}$ ). In terms of salinity, it is categorised as oligohaline, between $0-0.5 \%$ salinity, all year-around and generally well-mixed; however, stratification has been observed in the mid-estuarine region [22]. The land throughout the catchment is primarily used for agriculture, with the dairy industry being the primary economic activity [23]. Three sites adjacent the town, namely the Slob Bank, the Claycastle site and the Ballyvergan Marsh, have been identified as areas to develop good practices for the delivery of ES provided by the estuary and are referred to as the proposed development sites.

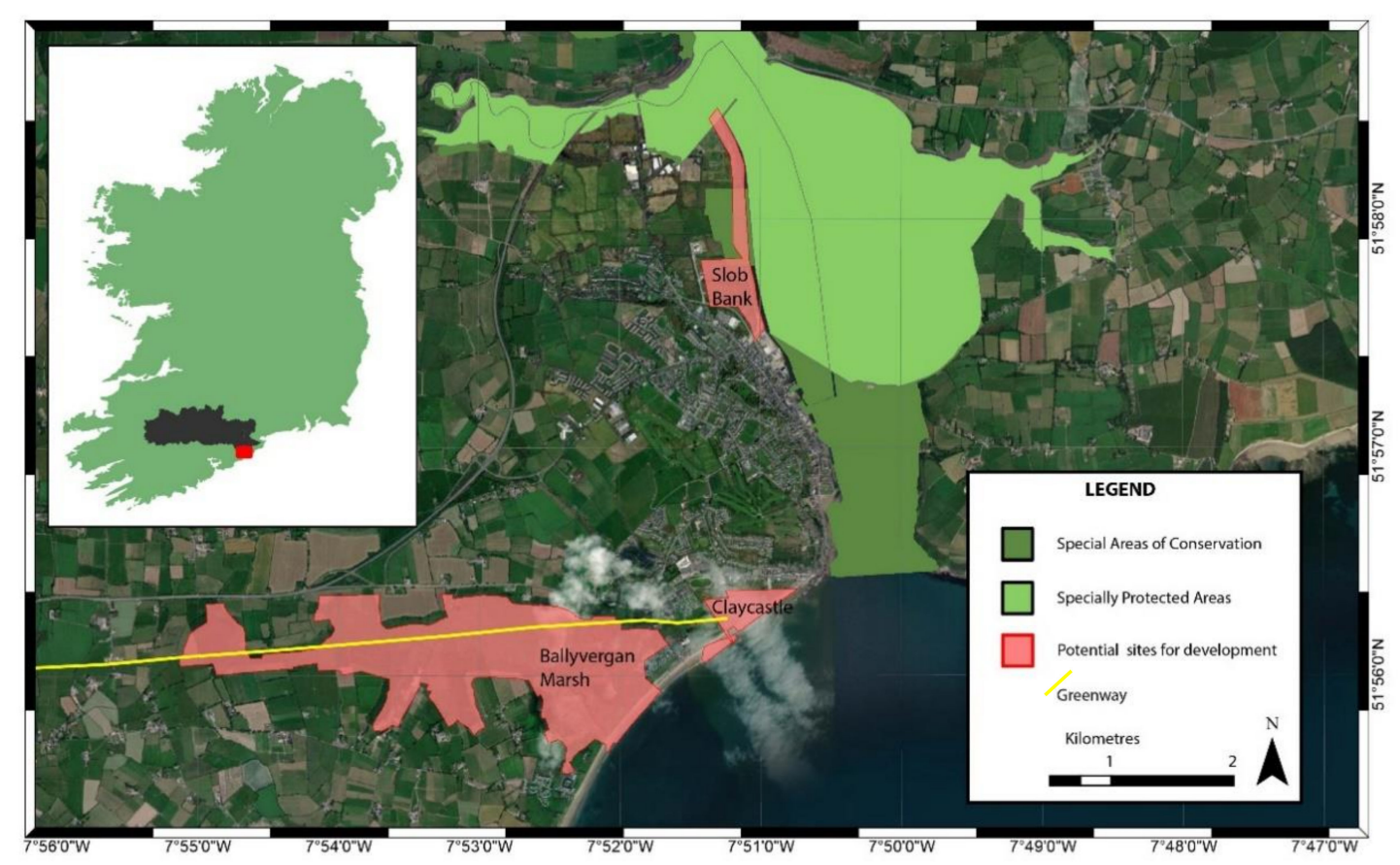

Figure 1. River Blackwater estuary and the proposed development sites. Special Area of Conservation, Special Protection Area, proposed natural heritage area and Midleton-Youghal Greenway route indicated. The location of the Blackwater catchment on the Island of Ireland is shown in the inset.

The concept of ES has been incorporated into the Regional Spatial and Economic Strategy (RSES) [24], in which the Blackwater estuary exists. However, there is still a lack of integration of the concept at the local scale $[25,26]$.

The Slob Bank (Figure 2) is a stone lined wall and embankment constructed over 150 years ago during the time of the Great Famine in Ireland as part of a public work programme. The land to the 
west is intertidal and attracts many species of waterfowl and sea birds. It also attracts certain species during the winter period. The estuary lies to the east of the Slob bank and provides an opportunity for anglers to fish and for bait-digging. The embankment is used as a walkway, which provides views of the River Blackwater and estuary and provides an opportunity for passive and immersive interactions with nature through activities such as bird watching and angling.

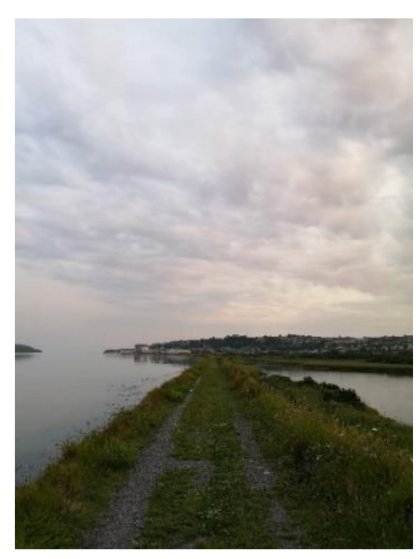

(a)

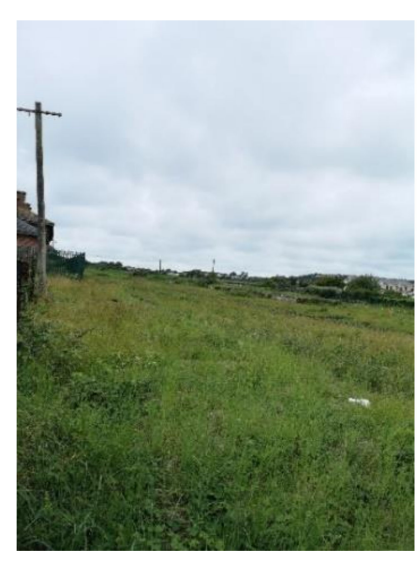

(b)

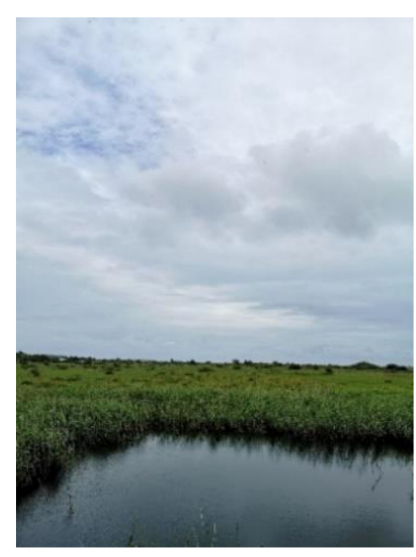

(c)

Figure 2. The proposed development sites. (a) The Slob Bank (b) the Claycastle site (c) the Ballyvergan Marsh.

The Claycastle site (Figure 2) is 21-acre area lying to the south of Youghal town and sits at the mouth of the River Blackwater. On the east side of the site lies a derelict train station, and to the west, caravan parks and a pitch and putt club divides the site from the Ballyvergan Marsh. The site has been derelict for over 35 years. The site runs alongside the Claycastle beach and borders the 378 metre Eco-boardwalk, which is currently being extended, where there is an opportunity for birdwatching and observing sea life. The new Midleton to Youghal Greenway, which is in the early stages of implementation, will run through this site, beginning at the derelict train station. Data has been gathered on pluvial and coastal flooding on the site, which also shows at what temporal scales to expect these floods. The area is naturally well-defended against coastal flooding [27].

The Ballyvergan Marsh (Figure 2) is a marshland lying southwest of Youghal town. The marsh itself is the largest freshwater coastal marsh in County Cork and is home to well-developed plant communities as well as being an established breeding ground for bird species such as reed warblers (Acrocephalus scirpaceus) [28]. It is also a proposed natural heritage area. The new proposed Midleton to Youghal Greenway will also continue east to west through the entirety of the marsh. Many fields south of the forthcoming Midleton to Youghal Greenway are in agricultural use. The marsh acts as a regulatory zone between fresh and saline water. It is also likely to have other water-based regulatory effects, such as on the groundwater flow and on flooding. Data on pluvial, fluvial and, especially, coastal flooding in the marsh land have been gathered, which show areas that have flooded in the past and at what temporal scales to expect these floods [29]. Other regulating ES include the maintenance of nursery populations and habitats, which aids cultural ES.

\subsection{Related Policies and Good Practices}

Policy documents that relate to the area are the RSES, Cork 2050, the Cork County Development Plan, the East Cork Municipal District Local Area Plan and the Youghal Town Development Plan 2009-2015. These reflect policies that apply to the estuary and the proposed development sites from a regional to local level. Good practices that have been identified in the area include the Midleton-Youghal Greenway Approval Process, the Youghal Eco-Boardwalk, the Ballyvergan Marsh 2017 Biodiversity Action Plan and the South East Cork Area Development (SECAD) Bird Hide. These reflect recent or 
ongoing projects, project processes and techniques that may be of interest to another region. These have been proved successful where they have produced measurable results that relate to a particular objective [30].

\subsection{Data Collection}

Figure 3 illustrates the main steps in the development and application of the ES assessment methodology for the three sites. The first step was the identification and characterisation of the three sites through interviews with local stakeholders in Youghal Town Council and in Cork County Council. In order to facilitate analysis, and based on the characteristics of the sites, a shortlist of biotic and abiotic ES was drawn up from the CICES v5.1 classification scheme. This shortlist contained 50 biotic and 23 abiotic ES from the 99 total classes of ES contained within CICES. After an initial trial, the survey was refined, with some ES being amalgamated for ease of understanding (e.g., Dilution of waste or pollutants by freshwater and marine ecosystems (5.1.1.1), Dilution of airborne pollutants by the atmosphere (5.1.1.2) and Natural processing of wastes (e.g., pollutants filtered out as water seeps through the soil) (5.1.1.3) became "Dilution and natural processing of waste and pollutants" (e.g., by a river, by soil, by the atmosphere)). The ES were assessed through deployment of a survey instrument to relevant stakeholders. Two groups of stakeholders were identified; interested residents (the public) were targeted through local Facebook groups, and stakeholders professionally involved in regional development termed the Regional Stakeholder Group (RSG) were targeted by email. The RSG was formed as a part of the Delta Lady project. The members include Cork County Council, the Southern Regional Assembly, the EPA, the Youghal Socio-Economic Development Group, the Local Authority Waters Programme, Teagasc, Inland Fisheries Ireland and the Department of Agriculture, Food and the Marine (An Roinn Talmhaíochta, Bia agus Mara). This survey was cleared by the Faculty of Behavioural, Management and Social Sciences ethical committee from the University of Twente, and permission to use respondent's data was requested prior to answering the survey.

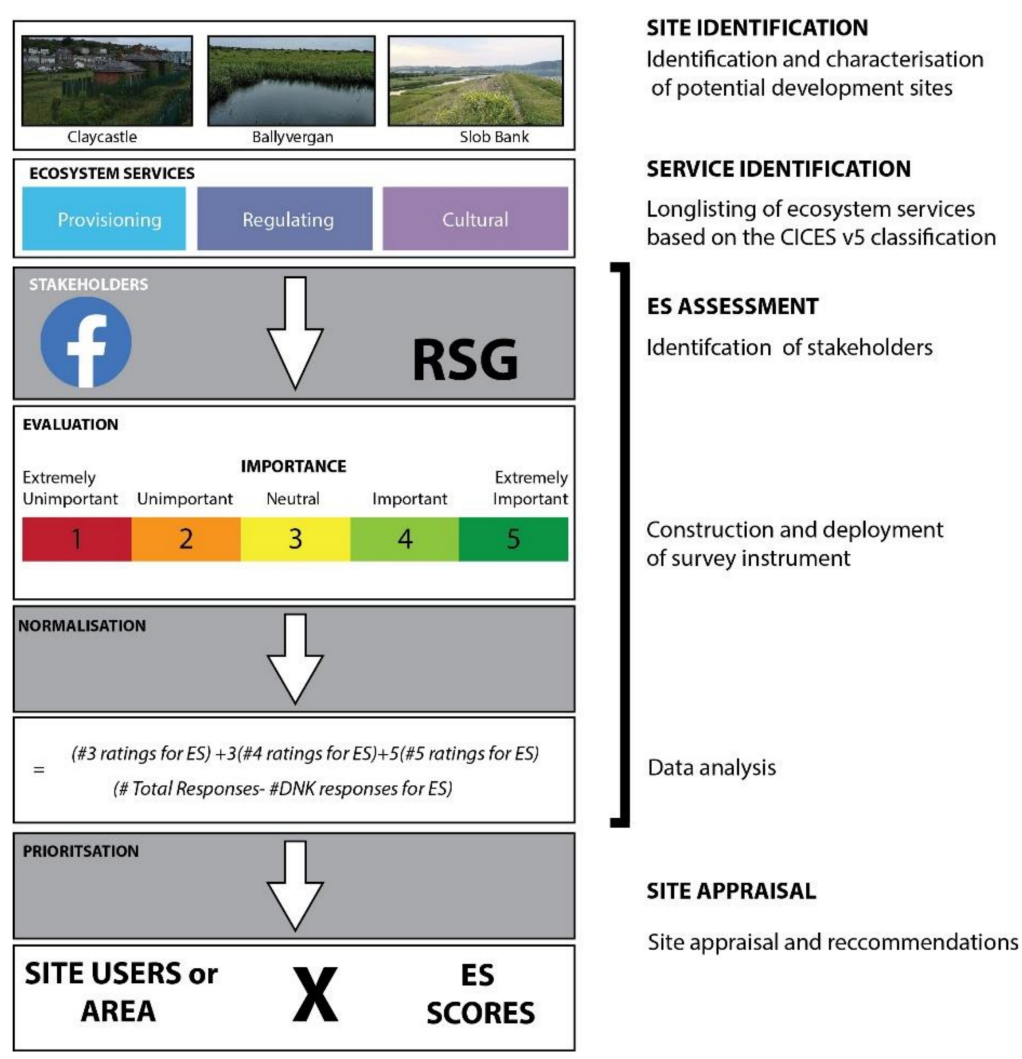

Figure 3. Schematic diagram of the Ecosystem Services Assessment methodology. 
Respondents were first asked a number of questions about their level of site use and their personal priorities for the types of development which should be undertaken at the site. Next respondents were asked to rate the importance of each of the subsets of ES identified using a Likert scale (see Figure 3) [31]. Table 1 provides a summary of the questions asked in the survey instrument. The survey used language adapted from the "simple descriptors" which is used in CICES V5.1 to describe specific ES in the most basic manner.

Table 1. Summary information on the questions included in the survey instrument.

\begin{tabular}{|c|c|c|c|}
\hline Questions & Survey & Example & Options \\
\hline $\begin{array}{l}\text { Q1 Proximity to the River } \\
\text { Blackwater estuary }\end{array}$ & Public & $\begin{array}{l}\text { How far do you live from the River } \\
\text { Blackwater estuary? }\end{array}$ & $<2 \mathrm{~km}, 2-4 \mathrm{~km}, 4-10 \mathrm{~km}, 10 \mathrm{~km}+$ \\
\hline $\begin{array}{l}\text { Q2, 4, } 6 \text { Relating to the use of the } \\
\text { proposed development sites }\end{array}$ & Public & $\begin{array}{c}\text { How often do you use the Slob Bank } \\
\text { for walking, birdwatching, } \\
\text { observing other nature, fishing, } \\
\text { bait digging? }\end{array}$ & $\begin{array}{c}\text { Every day, } 2-6 \text { times a week, } \\
\text { 1-6 times a month, }<1 \text { a month, } \\
\text { Never. }\end{array}$ \\
\hline $\begin{array}{l}\text { Q3, 5, } 7 \text { Relating to how often } \\
\text { people see the proposed } \\
\text { development sites }\end{array}$ & Public & $\begin{array}{l}\text { How often do you see the } \\
\text { Claycastle site? }\end{array}$ & $\begin{array}{c}\text { Every day, } 2-6 \text { times a week, } \\
1-6 \text { times a month, }<1 \text { a month, } \\
\text { Never. }\end{array}$ \\
\hline $\begin{array}{l}\text { Q8 Suggestion on development of } \\
\text { the proposed development sites }\end{array}$ & Public & $\begin{array}{c}\text { What amenities or services would } \\
\text { encourage you to use these } \\
\text { sites more? }\end{array}$ & Open text field \\
\hline $\begin{array}{l}\text { Q9-14 Importance rating for } \\
\text { specific ES }\end{array}$ & Public and RSG & $\begin{array}{l}\text { How would you rank the following } \\
\text { biotic regulating ES by level of } \\
\text { importance in the Blackwater } \\
\text { Estuary and the surrounding sites } \\
\text { on a scale from 1-5 (See Figure 3)? }\end{array}$ & $\begin{array}{l}\text { Extremely Unimportant, } \\
\text { Unimportant, Neutral Important, } \\
\text { Important, Extremely Important, Do } \\
\text { Not Know. }\end{array}$ \\
\hline \multirow{6}{*}{ Q15 Why ES are important } & \multirow{6}{*}{ Public and RSG } & \multirow{6}{*}{$\begin{array}{l}\text { What are the most important factors } \\
\text { when considering why an } \\
\text { ecosystem service is important? } \\
\text { Please rank the following from least } \\
\text { important to most important. }\end{array}$} & $\begin{array}{l}\text { 1. Local businesses benefit } \\
\text { economically, }\end{array}$ \\
\hline & & & $\begin{array}{l}\text { 2. Encourages new businesses and } \\
\text { industries to be set up in the area, }\end{array}$ \\
\hline & & & $\begin{array}{l}\text { 3. Attracting tourism/ecotourism } \\
\text { leading to economic and gain, }\end{array}$ \\
\hline & & & $\begin{array}{l}\text { 4. Enhancing flood protection, } \\
\text { carbon storage and regulation of } \\
\text { climate-related processes, }\end{array}$ \\
\hline & & & 5. Enhancing social wellbeing, \\
\hline & & & $\begin{array}{l}\text { 6. Protecting native species and } \\
\text { existing habitats }\end{array}$ \\
\hline \multirow{5}{*}{ Q16 Development method } & \multirow{5}{*}{ Public and RSG } & \multirow{5}{*}{$\begin{array}{l}\text { What is the preferred development } \\
\text { method for improving ES? Please } \\
\text { rank the following from least } \\
\text { desirable to most desirable. }\end{array}$} & 1. Leave nature to its own accord, \\
\hline & & & $\begin{array}{l}\text { 2. Minimal development-few } \\
\text { facilities but accessible, }\end{array}$ \\
\hline & & & $\begin{array}{l}\text { 3. Medium development-Some } \\
\text { damage to the environment and } \\
\text { better facilities, }\end{array}$ \\
\hline & & & $\begin{array}{c}\text { 4. High } \\
\text { development-Considerable } \\
\text { damage to the environment but } \\
\text { many useful facilities and amenities, }\end{array}$ \\
\hline & & & $\begin{array}{l}\text { 5. Full development-Natural } \\
\text { environment is completely } \\
\text { transformed; however, a } \\
\text { semi-natural environment is created } \\
\text { and extensive facilities and } \\
\text { amenities are available }\end{array}$ \\
\hline \multirow{3}{*}{ Q17 Site Preference } & \multirow{3}{*}{ Public } & \multirow{3}{*}{$\begin{array}{l}\text { Which site do you think has the } \\
\text { most potential to deliver the } \\
\text { ecosystem services that you value? }\end{array}$} & 1. Slob Bank \\
\hline & & & 2. Ballyvergan Marsh \\
\hline & & & 3. Claycastle site \\
\hline
\end{tabular}

Supplementary supporting data was gathered through open text fields in the online survey. Open coding was used to synthesise information from the qualitative data that was gathered. To achieve this, categories were established in which the information from qualitative questions could be placed, and then categories that were judged to be intrinsically linked were combined to turn the data into 
useful information. This was adapted from a grounded theory approach for the case study approach taken in this research.

Results from the Likert scales were analysed to produce a value rating based on Washbourne et al. (2020) [32] using the formula below. Washbourne et al. (2020) used a weighted system to put a greater value on important and extremely important ratings.

$$
\begin{aligned}
& \text { Importance rating for an ecosystem service }(E S) \\
& =\frac{(\# 3 \text { ratings for } E S)+3(\# 4 \text { ratings for } E S)+5(\# 5 \text { ratings for } E S)}{(\# T \text { total Responses }-\# D \text { Do not know responses for } E S)}
\end{aligned}
$$

The value ratings for each service were combined with estimates of the levels of service supply and demand. For cultural services, demand was estimated based on the levels of interaction (number of annual views of a particular site based on question 3, 5 and 7 of the survey); for regulating services, (several of which were not final services) the service was assumed to scale with ecosystem processes, and the amount of habitat present was used as a simplifying proxy. For both cultural and regulating services, the value rating (based on the Likert results) was multiplied by the level of service supply/demand. Since the area-based estimates of supply for regulating services could not be assumed to be equivalent to the use-based estimates of demand for cultural services, the total values for each service were scaled relative to each other where the highest value in each category (regulating or cultural) was assumed to be worth $100 \%$, with other services being expressed as a percentage of this total. The simple assumption, to enable comparison, was that the highest valued cultural service was equal in value to the highest valued regulating service. The services were then summed to give total values for each category, which were comparable across all three sites.

A policy analysis was also undertaken. Documents related to policies which effect the area and good practices that could be identified underwent an evaluation as data sources. Good practices are defined as "initiative[s] (e.g., project, project process, technique) which have proved to be successful in a region and which are of potential interest to other regions. Proved successful is where the good practice has already provided tangible and measurable results in achieving a specific objective" [30]. The primary aim of these reviews was to establish how ES were portrayed in policy, either explicitly or implicitly, which policy instruments (based on those identified in [18]) underpinned these portrayals and how these policies had manifested as good practices.

\section{Results}

\subsection{Survey Completion}

In total, there were 99 responses to the surveys. Full completion rates for the survey were considerably fewer with a total of 44 individual completing the entire survey. The breakdown of completion was 34 of 89 in the public survey and 10 of 10 in the RSG survey. The drop-offs in the public survey response shows a distinctive pattern with almost $60 \%$ of respondents exiting the survey when the first questions relating to ES were introduced; a similar smaller drop-off was observed when the questions moved from biotic ES to abiotic ES (Figure 4). Respondents' comments in the open fields in the survey suggested that this drop-off may have been due to inaccessibility of the language (Box 1), while the number of questions in the survey may have also had an effect on the drop off. 


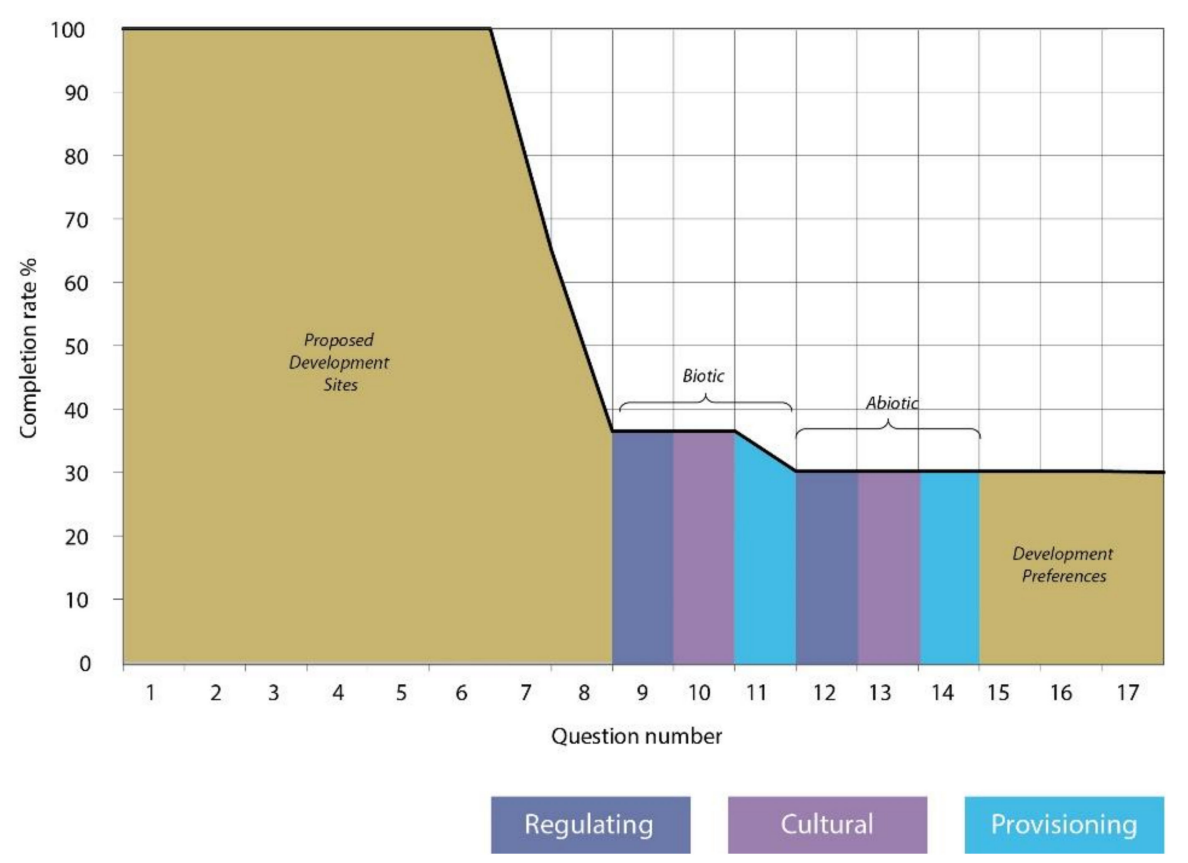

Figure 4. The drop off rate from the public survey. The topics which the questions address are also shown.

Box 1. Facebook comments on the survey.

"Many people are very interested in the topics that you raise but might find the concepts and language of the questionnaire
difficult to grasp"
"I was bored to death and gave up on the first one"

Despite the fall-off in responses over the course of the survey, there were still sufficient data to make a comparison between the values placed by respondents on each ecosystem service. Of the 73 services shortlisted for the survey, mean values greater than 3.5 were calculated for just 18 services (24.7\%); these included 8 regulating services, 9 cultural services and 1 provisioning service. The mean scores for each of these services is illustrated in Figure 5. The regulating service of pollination and water flow regulation scored as did the cultural service for passive activities, natural beauty, bequest values, active recreation and cultural heritage. Of the regulating services several, including pollination, nursery and spreading seeds are intermediate services, and others, such as regulation of water flow (biotic and abiotic), waste decomposition, water quality and climate regulation, are final services. Where the regulatory services of a habitat, such as a marsh, were not fully understood by the respondents, this may have had the effect of skewing the results in the favour of cultural service. In a paper by Brown et al. [33], a highly educated, knowledgeable audience found it much easier to identify cultural ES, while they found the identification of regulating and supporting ES to be the most difficult using public participation geographic information systems. This simple assumption, although useful, does fail to consider the degree of delivery of specific ES, the relationship between services and drivers of these services and the direct or indirect impact services have on one another [34]. The consideration and investigation of such relations would be of great benefit to the method but would greatly increase its complexity, and hence the time and money needed to conduct the assessment. 


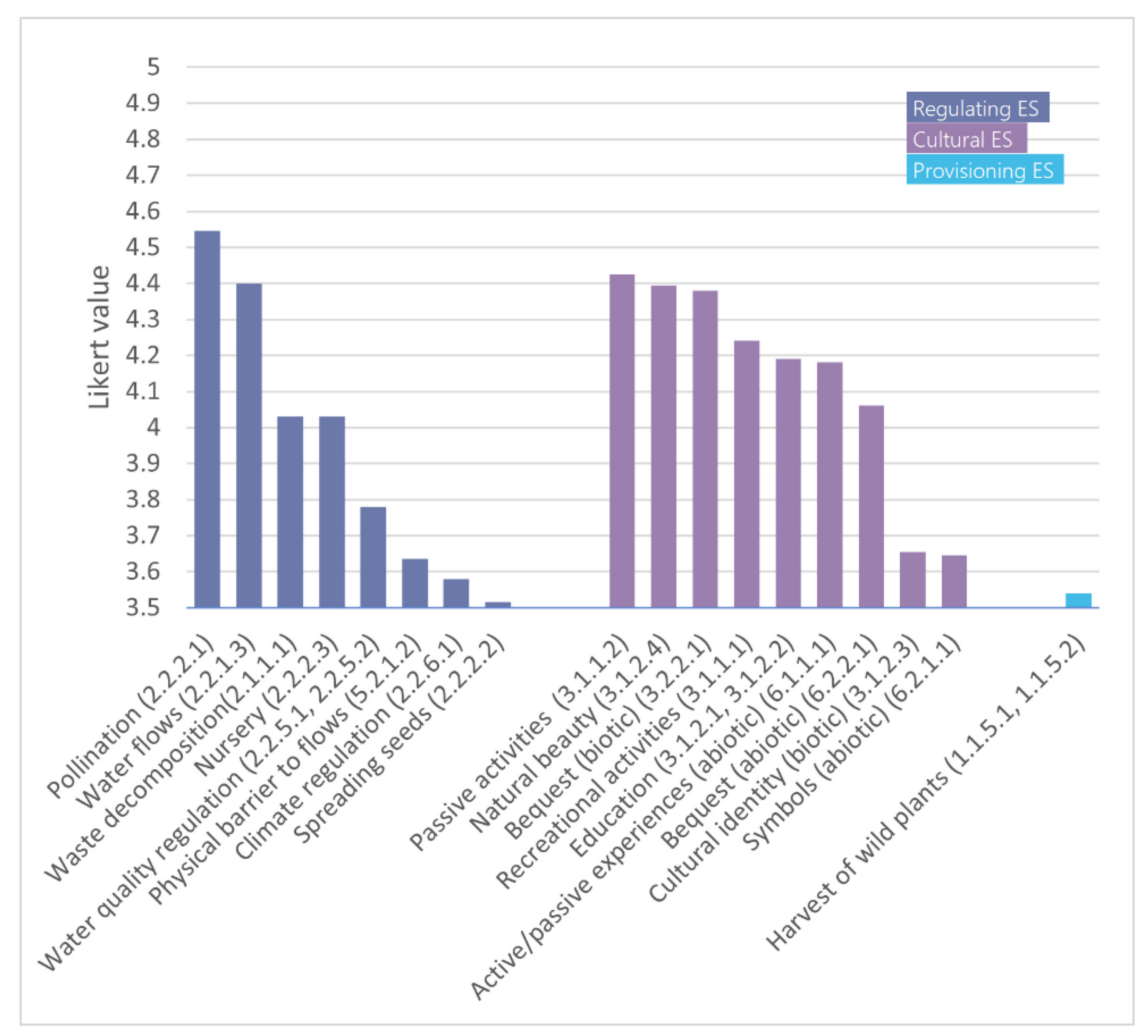

Figure 5. Average Likert values for biotic and abiotic ecosystem services considered important or extremely important in the study area.

Figure 6 shows the number of interactions reported by respondents on an annual basis over a one-year period. Respondents had the highest levels of interaction with the slob bank, with $70 \%$ reporting viewing the site every day or more than once a week, with the Claycastle site being second (62\%); just $38 \%$ of respondents saw the Ballvergan Marsh more than once a week, and $28 \%$ had never seen the marsh. While the time intervals for the assessment of the site introduced an element of uncertainty into the exact use levels (e.g., 2-6 times a week implies a visitation of between 104 and 312 ), it was nevertheless possible to make estimates of usage rates per 100 population per year for each site. The total use-rate estimated were 22,340 ( $\max 25,241-\min 19,439), 17,474(\max 22,105-\min 12,951)$ and 11,147 ( $\max 14,154-\min 8110)$ for implying mid value daily use rates of $0.6,0.5$ and 0.3 per day for Slob Bank, Claycastle and Ballyvergan, respectively.

The aggregated ES value for the three service categories at each site is shown in Figure 7. Overall, the aggregate scores for all three categories were highest in the Ballyvergan marsh followed by Slob Bank and Claycastle; however, this was principally driven by the high values for regulating services, particularly abiotic services, in Ballyvergan marsh calculated due to its much larger geographic area (calculated as supply side). Considering cultural services, the Slob Bank was the most valued site, followed by Claycastle, then Ballyvergan, and this pattern reflected the estimated use levels or demand side for the sites. Of the respondents who completed the survey, $50 \%$ indicated they would like to see the Slob Bank developed, 29.4\% indicated the Ballyvergan Marsh and 20.6\% indicated the Claycastle site, and this order of priority reflected our aggregated services supply and demand estimates. 


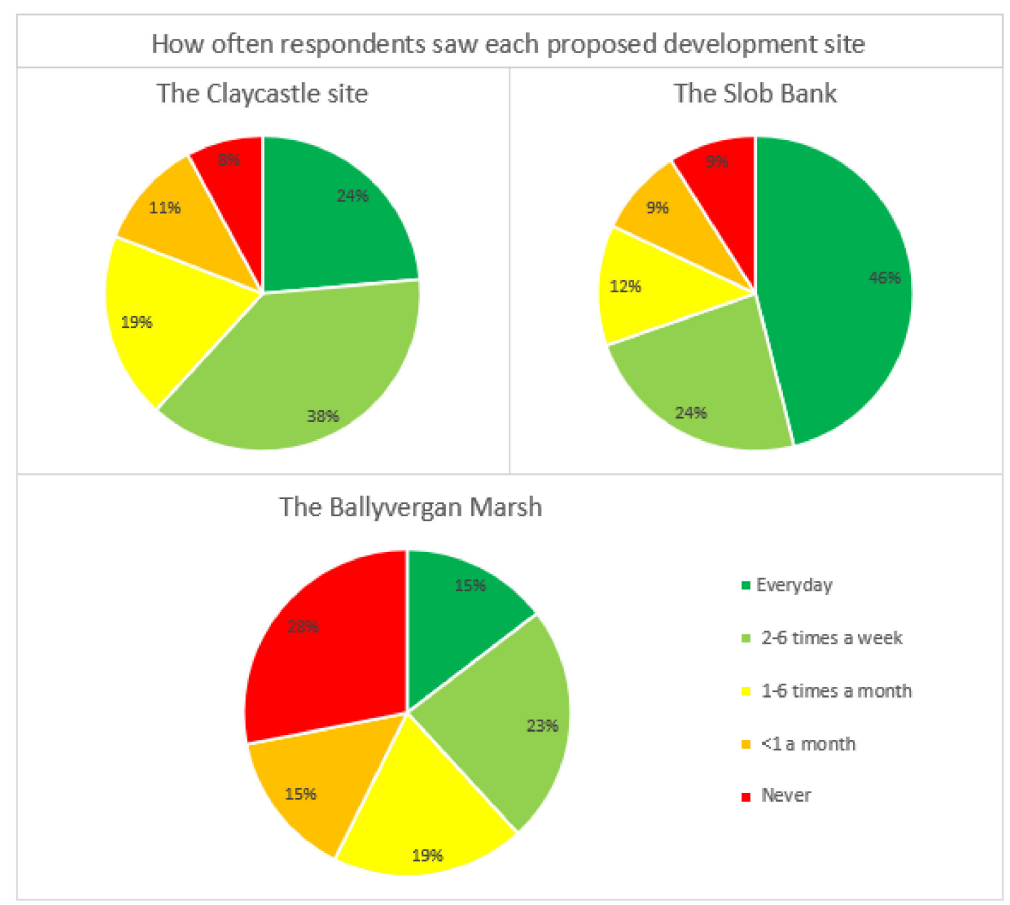

Figure 6. Use rates for the three sites used to calculate overall cultural ecosystem service scores.

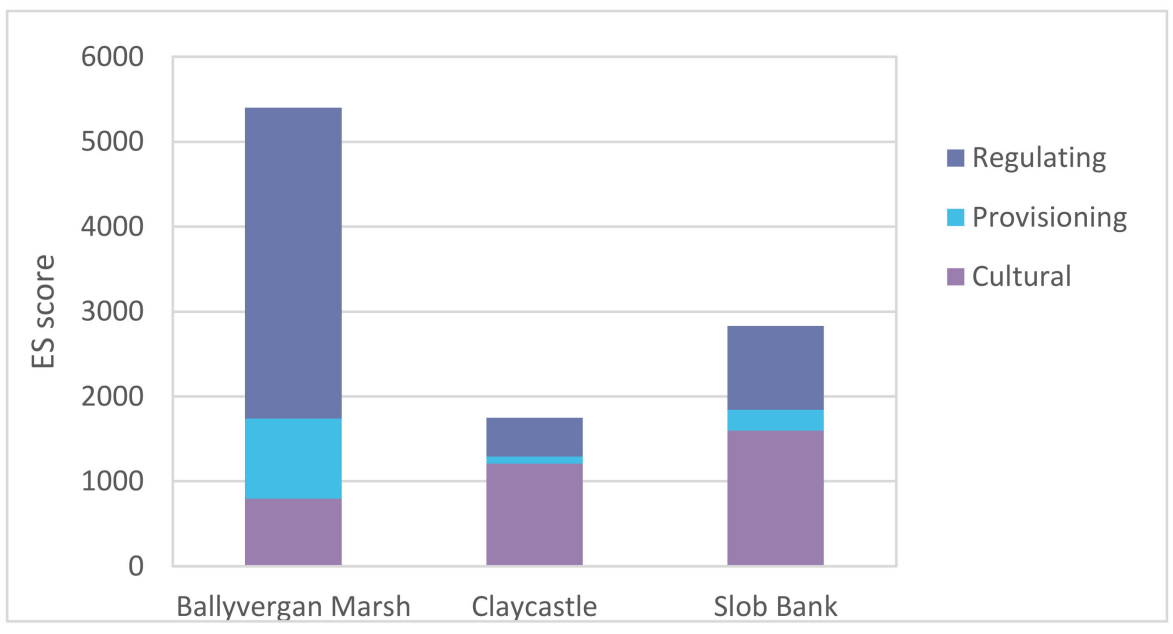

Figure 7. Aggregated abiotic and biotic ecosystem service values for the three sites.

Of 89 respondents, $65.2 \%$ lived within $2 \mathrm{~km}$ of the estuary and $92.1 \%$ of people lived within $10 \mathrm{~km}$. A total of $66.3 \%$ (53/80) of people said they never part took in observing nature in the Ballyvergan Marsh, while the same figure was $27.4 \%$ (23/84) for the Claycastle site and 34.9\% (30/86) for the Slob Bank. In relation to stakeholder prioritisation, on average the surveys indicated that minimal development was the preferred development method (3.835). Medium development (3.35) and leave nature to its own accord (3.345) were also rated highly. High development (2.305) and full development (2.41) were generally unpopular.

For the options given as to why ES enhancement is important, protecting native species and existing habitats (4.77) and enhancing social wellbeing (4.25) ranked highest in the surveys. It is worth noting that enhancing social wellbeing ranked first in the public survey while the results were collected during the COVID-19 lockdown. Enhancing flood protection, carbon storage and regulation of climate-related processes (3.895) was also ranked highly, while the lower ranked options related to tourism (2.94) and increased business performance (3.015)/new local business (2.355). 
The Youghal-Midleton Greenway, which is currently in the early stages of development, had a big influence on the open text field responses for both the Claycastle site and the Ballyvergan Marsh, with $25.5 \%$ (12/47) and $44.4 \%$ (20/45) of respondents, respectively, mentioning the greenway or suggesting a walkway be implemented. Other amenities that were popular at the Claycastle site included seating areas and bins/dog-fouling bins. At the Ballyvergan Marsh, the most common response aside from that of the greenway was that of better access and promotion and more observation areas. It was stated by one respondent that the current SECAD bird hide is not open to the public. For the Slob Bank, the most sought-after amenity was the development of the walkway $(37.7 \%(20 / 53))$. This included suggestions about making the walking route circular and improving the surface. Other popular suggestions were flora/fauna/history signage, seating areas, (sheltered) observation areas and bins/dog-fouling bins. Calls for the preservation and the protection of these sites were also voiced by several respondents: $17.8 \%$ (8/45), Ballyvergan Marsh; 10.6\% (5/47), Claycastle site; and 5.7\% (3/53), Slob Bank.

\subsection{Policy Analysis}

The Regional Spatial Economic Strategy (RSES), Cork 2050 and the forthcoming Cork County Development Plan 2022 have incorporated the concept of ES explicitly. The concept is noted to underpin green infrastructure $[24,35,36]$. Green infrastructure:

“... promote[s] the concept of connecting corridors [of green and blue spaces] for the movement of wildlife and encourage the retention and creation of features of biodiversity value, ecological corridors and networks that connect areas of high conservation value".

All policy instruments from Schmidt and Seppelt (2018) [18] were identified either explicitly or implicitly in the policy document analysis. Regulating use through protected areas and recognition of their value and direct public investment in ecological infrastructure and restoration were referenced consistently at both regional and local scales. "Regional Policy Objective 110 Ecosystem Services" is described in the RSES [24]. It considers how the valuation of an ecosystem could help determine if a policy arrangement would enhance a particular aspect of that ecosystem. It also makes reference to the connection between ecology and economics through a payment for ES scheme [24]. This indicates two policy instruments: extending accounting systems through nature-based indicators and rewarding benefits through payment markets.

The good practices identified in the area are related to several policy instruments and look to enhance different ES categories. The Youghal Eco-boardwalk and its extension to Redbarn (under construction as of date of writing) and the SECAD bird hide are projects that reflect the policy instrument, direct public investment in ecological infrastructure and restoration, and relate to enhancing cultural ES. The Ballyvergan Marsh 2017 Biodiversity Action Plan [37] supports regulating use through protected areas and recognition of their value while also offering structure for the possibility of extending accounting systems through nature-based indicators. The Biodiversity Action Plan implicitly aims to ensure that specific ES regulations remain intact and the areas of biodiverse nature are not damaged. Finally, the Midleton to Youghal Greenway approval process demonstrates the importance of rigorous reporting [28,38-40] and extensive stakeholder participation in projects, especially with regard to a sensitive ecological area such as the Ballyvergan Marsh, and when it comes to issues such as land ownership. This reflects the policy instrument, regulating use through protected areas and recognition of their value and the investigation into how such a project would affect biotic and abiotic ES regulating undertaken in the reporting. In addition, the financing of the restoration and repurposing of the old railway line shows that direct public investment in ecological infrastructure and restoration is taking place. 


\section{Discussion}

A method of assessing ES was developed and applied to three sites adjacent to the Blackwater estuary. Despite a limited sample size and a high drop-off rate, the exercise provided some useful insights into the state-of-the-art in assessment of ES as well as providing a low cost easy to deploy method for assessment of ES between sites.

Perhaps the most notable result from our survey was the high drop off rate. While most respondents were willing and able to provide information about their use of sites and their environmental values, when faced with the assessment of ES themselves based on the CICES v5.1 simple descriptors, $60 \%$ of respondents were unwilling or unable to respond. Our data indicate that this was due to inaccessibility of the language rather than lack of engagement with the subject. This problem with the language of ES has been noted by other authors [41]. Critically, since the holistic assessment of ES requires input from engaged relevant stakeholders, if the language used to describe ES is difficult to understand, off-putting or unengaging, the language of the analysis has the potential to undermine the outputs of the assessment. While the importance of classifying ES is not in question, it may be the case that the natural science tradition with its long history and emphasis on classification has influenced the CICES unduly, and at very least it should be recognised that the current set of "simple descriptors" is not suitable for stakeholder engagement. For example, Flood et al. (2020) [41] point out that

"While anybody can understand the concept of 'a beautiful view' this, same concept is perhaps not optimally expressed as 'Intellectual and representative interactions with abiotic components of the natural environment'".

If ES concepts are to be representative of public values as a basis for practical management decisions, there is a clear requirement to improve the language for improved public communication. While recognising this problem, the assessment also suggested that there is clear potential for the public to engage with ES concepts. For example, the most highly valued ecosystem service was that of pollination. This may be due to public engagement with the idea of pollination, which has been promote nationally through the All-Ireland's Pollinator Plan [42]. A clear importance placed on this service is comparable to the importance placed on keystone species in [43,44]. In a similar fashion we can establish keystone ES and use this status to create aims around the service. A lesson from the Spanish partners in the Delta Lady project is the Rice of Albufeira. The provisioning of this rice (a final provisioning ES) is being further used to enhance agro-tourism and birdwatching (cultural ES) in the region, which shows how emphasis placed on an important ES in a region can influence other services, which ideally lead to synergistic benefits. It is noteworthy that in the case of our three sites, pollination is not a final service; rather, the benefits from pollination flow to the public through the process of pollination to the cultural services experienced directly through the production of flowers and other plants and interactions with these elements. Thus, the concept of pollination and its importance are clearly understood despite the fact that it is an intermediate service.

This leads to another issue with the CICES. It has long been established that in the assessment of ES and for natural capital accounting, there is a need to avoid double counting and to make an essential distinction between intermediate and final services [14,15]. This distinction is not explicit with the current CICES. In our aggregate assessment (Figure 7), there may be an element of double counting, since pollination, nursery and spreading seeds are all intermediate services that contribute to the final cultural services, which were also assessed. This suggest that further work is required on the CICES; this could include an additional data descriptor pertaining to the services as being intermediate or final (which may vary cases by case).

Acknowledging the limitations of survey size and completion rates, the simplifying assumption that regulating services scale with habitat size and the uncertainty associated with the visitation rates used to approximate demand for cultural service, our methodology nevertheless enabled us to make a ES value-based assessment across the three sites in question using public values for ecosystem services, which could help to inform local development choices. We note that the cultural services component of 
our ES assessment is in agreement with the stakeholder priorities for site development, i.e., Slob Bank then Ballyvergan Marsh then Claycastle. It is also noteworthy that Ballyvergan Marsh, the site which perhaps has the most ecological value (being a large, relatively undisturbed site as well as a proposed Natural Heritage Area), is not necessarily the site which, if made more accessible, would provide the greatest benefits, particularly in terms of cultural services. Applying complementary capital (social, human and man-made or built capital) to the natural environment (intermediate and final ES) can result in the provisioning of societal goods and services which can impact societal welfare, positively or negatively $[45,46]$. For example, the proposed greenway project, which will improve access to the Ballyvergan site and may also attract higher numbers of visitors and improve the delivery of cultural ecosystem services from this site, and a similar assessment following the opening of the greenway could provide interesting insights into the temporal patterns of ES flow and the importance of complementary capital.

The Cork County Development Plan 2022 provides an opportunity to draw from policy instruments and concepts that have been developed in preceding policy documents. Although the concept of ES is described within the RSES, Cork 2050 and the public consultation document for the new Cork County Development Plan 2022, the details required to systematically engage with the concept remain unsubstantial. The use of the term "ecosystem services" in RSES and Cork 2050 is explicitly implied as underpinning the term "green infrastructure". The link between green infrastructure and certain ES has been implicitly considered in development, e.g., SECAD bird hide and greenway, but explicit consideration might have made the former more successful. However, the link between green infrastructure and other ES, such as bioremediation or the use of genetic material from plants and animals for enhancing a population elsewhere, is not immediately apparent. It would seem plausible that ES should be established as a core category within the Cork County Development Plan 2022, under which green infrastructure could be established as a subsection, along with it being a complimentary text within other categories such as Transport and Mobility, Built and Natural Heritage, and Tourism.

Two policy instruments, namely direct public investment in ecological infrastructure and restoration and regulating use through protected areas and recognition of their value are already prominent in current policy plans, as well as good practices, and could continue to play an important role in an ES strategy for the River Blackwater estuary area. Extending accounting systems through nature-based indicators and rewarding benefits through payment markets are the other two chosen instruments which form this ES strategy. These instruments, which have been alluded to within the RSES and the Ballyvergan Marsh 2017 Biodiversity Action Plan, may form the basis for action plans from such accounting systems. There is work to be done to operationalise these instruments; however, investigating this may form a mid- to long-term objective related to the development of the concept of ES within the context of a local area.

\section{Conclusions}

There is a clear requirement to improve the CICES scheme if it is to be widely operationalised in public decision-making. In particular, the language describing ES needs to be made more accessible. This could be achieved through a formal survey into the effectiveness and accessibility of alternative wording to express ecosystem service concepts. Secondly, clear distinction must be made in the system between final and intermediate services.

Regarding policy, there is an opportunity to incorporate ES as a core concept within the Cork County Development Plan 2022. The examination of how the concept can be operationalised is key to this being established. Learning from the success of the All-Ireland Pollinator Plan and the Rice of Albufeira good practice in the Delta Lady project, highlighting services of particular importance to a region (keystone ES) and directing extensive efforts to communicate this importance with the public is vital. The language used to communicate this message needs to be clear. The CICES could make a 
move to reinvent its simple descriptors as short documents to the public describing why a specific ecosystem service is important and regions of where it is of importance.

In terms of the assessment methodology employed here, there are a number of improvements that could be employed in further applications. Questionably, we assumed that the highest valued cultural ES was equal to the highest valued regulating ES. The limited number of participants who fully completed the survey meant that the results were not sufficient to make recommendations on the development of a proposed development site. The valuation technique was successfully deployed, however, and data analysis that was applied uncovered some useful information on the sites, which indicates that such a method would be useful for other partners on the Delta lady project.

Supplementary Materials: The following are available online at http://www.mdpi.com/2071-1050/12/21/9047/s1.

Author Contributions: Conceptualization, D.D.; methodology, D.D. and T.O.; software, T.O. and D.D.; validation, T.O.; formal analysis, D.D. and T.O.; investigation, D.D.; resources, D.D.; data curation, D.D.; writing-original draft preparation, D.D.; writing-review and editing, D.D. and T.O.; visualization, T.O. and D.D.; supervision, T.O.; project administration, D.D. All authors have read and agreed to the published version of the manuscript.

Funding: This research received no external funding.

Conflicts of Interest: The authors declare no conflict of interest.

\section{References}

1. NOAA (National Oceanic and Atmospheric Administration). Estuaries. 2019. Available online: https: //oceanservice.noaa.gov/education/pd/estuaries/welcome.html (accessed on 18 August 2020).

2. Millennium Ecosystem Assessment. Ecosystems and human well-being: Synthesis. In Assessment of Climate Change in the Southwest United States; Island Press: Washington, DC, USA, 2005. [CrossRef]

3. Nicholls, R.J.; Hutton, C.W.; Adger, W.N.; Hanson, S.E.; Salehin, M. Ecosystem Service for Well-Being in Deltas_Integrated Assessment for Policy Analysis; Springer Nature: Berlin/Heidelberg, Germany, 2018.

4. Costanza, R.; Arge, R.; de Groot, R.; Farber, S.; Grasso, M.; Hannon, B.; Limburg, K.; Naeem, S.; O’Neill, R.; Paruelo, J.; et al. The Value of the World's Ecosystem Services and Natural Capital. Nature 1997, 387, $253-260$. [CrossRef]

5. Costanza, R.; De Groot, R.; Braat, L.; Kubiszewski, I.; Fioramonti, L.; Sutton, P.C.; Farber, S.; Grasso, M. Twenty years of ecosystem services: How far have we come and how far do we still need to go? Ecosyst. Serv. 2017, 28, 1-16. [CrossRef]

6. TEEB (The Economis of Ecosystems and Biodiversity). The Economics of Ecosystems and Biodiversity Ecological and Economic Foundations; Kumar, P., Ed.; Earthscan: London, UK; Washington, DC, USA, 2010.

7. Haines-Young, R.; Potschin, M.B. Revision of the common international classification for ecosystem services (CICES V5.1): A policy brief. One Ecosyst. 2018, 3, 1-6. [CrossRef]

8. O’Higgins, T.; Nogueira, A.A.; Lillebø, A.I. A simple spatial typology for assessment of complex coastal ecosystem services across multiple scales. Sci. Total Environ. 2019, 649, 1452-1466. [CrossRef] [PubMed]

9. Boumans, R.; Costanza, R.; Farley, J.; Wilson, M.; Portela, R.; Rotmans, J.; Villa, F.; Grasso, M. Modelling the dynamics of the integrated earth system and the value of global ecosystem services using the GUMBO model. Ecol. Econ. 2002, 41, 529-560. [CrossRef]

10. Villa, F.; Ceroni, M.; Bagstad, K.; Johnson, G.; Krivov, S. ARIES (ARtificial Intelligence for Ecosystem Services): A new tool for ecosystem services assessment, planning, and valuation. In Proceedings of the 11th Annual BIOECON Conference on Economic Instruments to Enhance the Conservation and Sustainable Use of Biodiversity, Venice, Italy, 21-22 September 2009; pp. 21-22.

11. González-García, A.; Palomo, I.; González, J.A.; López, C.A.; Montes, C. Quantifying spatial supply-demand mismatches in ecosystem services provides insights for land-use planning. Land Use Policy 2020, 94. [CrossRef]

12. Teixeira, H.; Lillebø, A.I.; Culhane, F.E.; Robinson, L.; Trauner, D.; Borgwardt, F.; Kuemmerlen, M.; Barbosa, A.; McDonald, H.; Funk, A.; et al. Linking biodiversity to ecosystem services supply: Patterns across aquatic ecosystems. Sci. Total Environ. 2018, 657, 517-534. [CrossRef] [PubMed] 
13. Culhane, F.E.; Frid, C.L.J.; Gelabert, E.R.; White, L.; Robinson, L.A. Linking marine ecosystems with the services they supply: What are the relevant service providing units? Ecol. Appl. 2018, 28, 1740-1751. [CrossRef] [PubMed]

14. Fisher, B.; Turner, R.K.; Morling, P. Defining and classifying ecosystem services for decision making. Ecol. Econ. 2009, 68, 643-653. [CrossRef]

15. DeWitt, T.H.; Berry, W.J.; Canfield, T.J.; Fulford, R.S.; Harwell, M.C.; Hoffman, J.C.; Johnston, J.M.; Newcomer-Johnson, T.A.; Ringold, P.L.; Russell, M.J.; et al. The Final Ecosystem Goods \& Services (FEGS) Approach: A Beneficiary-Centric Method to Support Ecosystem-Based Management. In Ecosystem-Based Management, Ecosystem Services and Aquatic Biodiversity: Theory, Tools and Applications; Springer: Cham, Switzerland, 2020. [CrossRef]

16. Barbier, E.B.; Hacker, S.D.; Kennedy, C.; Koch, E.W.; Stier, A.C.; Silliman, B.R. The value of estuarine and coastal ecosystem services. Ecol. Soc. Am. 2011. [CrossRef]

17. Russel, D.; Jordan, A.; Turnpenny, J. The use of ecosystem services knowledge in policy-making: Drawing lessons and adjusting expectations. In Routledge Handbook of Ecosystem Services; Potschin, M., Haines-Young, R., Fish, R., Turner, R.K., Eds.; Routledge: London, UK, 2016; pp. 586-596.

18. Schmidt, S.; Seppelt, R. Information content of global ecosystem service databases and their suitability for decision advice. Ecosyst. Serv. 2018, 32, 22-40. [CrossRef]

19. Ramsar. Ramsar Sites Information Service. 2020. Available online: https://rsis.ramsar.org/ris/836 (accessed on 9 September 2020).

20. NPWS (National Parks and Wildlife Service). National Parks and Wildlife Service-Conservation Objectives Series: Blackwater River (Cork/Waterford) SAC 002170; NPWS: Dublin, Ireland, 2012.

21. NPWS (National Parks and Wildlife Service). National Parks and Wildlife Service-Conservation Objectives Series: Blackwater Estuary SPA 00402; NPWS: Dublin, Ireland, 2012.

22. O'Boyle, S.; Wilkes, R.; McDermott, G.; Ní Longphuirt, S. Will recent improvements in estuarine water quality in Ireland be compromised by plans for increased agricultural production? A case study of the Blackwater estuary in southern Ireland. Ocean Coast. Manag. 2017, 143, 87-95. [CrossRef]

23. O'Higgins, T. University College Cork: County Cork, Ireland, 2020; Unpublished work.

24. SRA (Southern Regional Assembly). Regional Spatial E Economic Strategy; Southern Regional Assembly: Waterford, Ireland, 2019.

25. Cork County Council. East Cork Municipal District Local Area Plan; Cork County Council: Cork, Ireland, 2017.

26. Youghal Town Council. Youghal Development Plan 2009-2015: Policies and Objectives; Youghal Town Council: Cork, Ireland, 2009.

27. Cork County Council. Midleton to Youghal Greenway Flood Risk Assessment; Cork County Council: Cork, Ireland, 2018.

28. AECOM. Midleton to Youghal Greenway—Appropriate Assessment Screening Report; AECOM: Dublin, Ireland, 2018.

29. OSI. GeoHive-Flood Maps, OSI. 2020. Available online: http://map.geohive.ie/ (accessed on 7 June 2020).

30. Interreg Europe. Interreg Europe Programme Manual; Interreg Europe: Lille, France, 2019; pp. 1-135.

31. Likert, R. A Technique for the Measurement of Attitudes. Arch. Psychol. 1932, 140, 1-55.

32. Washbourne, C.L.; Goddard, M.A.; Le Provost, G.; Manning, D.A.; Manning, P. Trade-offs and synergies in the ecosystem service demand of urban brownfield stakeholders. Ecosyst. Serv. 2020, 42. [CrossRef]

33. Brown, G.; Montag, J.M.; Lyon, K. Public Participation GIS: A Method for Identifying Ecosystem Services. Soc. Nat. Resour. 2012, 25, 633-651. [CrossRef]

34. Birkhofer, K.; Diehl, E.; Andersson, J.; Ekroos, J.; Früh-Müller, A.; Machnikowski, F.; Mader, V.L.; Nilsson, L.; Sasaki, K.; Rundlöf, M.; et al. Ecosystem services-current challenges and opportunities for ecological research. Front. Ecol. Evol. 2015, 1-12. [CrossRef]

35. Cork County Council. CORK 2050|Realising the Full Potential; Cork County Council: Cork, Ireland, 2017.

36. Cork County Council. Cork County Development Plan Review-Public Consultation Document; Cork County Council: Cork, Ireland, 2020.

37. SECAD (South and East Cork Area Development). Ballyvergan Marsh 2017 Biodiversity Action Plan; SECAD: Cork, Ireland, 2017.

38. AECOM. Midleton to Youghal Greenway_EIA Screening; AECOM: Los Angeles, CA, USA, 2018.

39. AECOM. Midleton to Youghal Greenway_Ecology Report; AECOM: Los Angeles, CA, USA, 2018.

40. Atkins. Midleton to Youghal Greenway_Flood Risk Assessment; Atkins: Epsom, UK, 2018. 
41. Flood, S.; O’Higgins, T.G.; Lago, M. The Promise and Pitfalls of Ecosystem Services Classification and Valuation. In Ecosystem-Based Management, Ecosystem Services and Aquatic Biodiversity; Springer Nature: Berlin/Heidelberg, Germany, 2020; pp. 87-103. [CrossRef]

42. FitzPatrick, Ú.; Stout, J.; Bertrand, C.; Bradley, K.; Clabby, G.; Keena, C.; Walsh, J. All-Ireland Pollinator Plan 2015-2020; National Biodiversity Data Centre: Waterford, Ireland, 2015.

43. Uprety, Y.; Asselin, H.; Bergeron, Y. Preserving ecosystem services on indigenous territory through restoration and management of a cultural keystone species. Forests 2017, 8, 194. [CrossRef]

44. Longland, W.S.; Ostoja, S.M. Ecosystem Services from Keystone Species: Diversionary Seeding and Seed-Caching Desert Rodents Can Enhance Indian Ricegrass Seedling Establishment. Restor. Ecol. 2013, 21, 285-291. [CrossRef]

45. Atkins, J.P.; Burdon, D.; Elliott, M.; Gregory, A.J. Management of the marine environment: Integrating ecosystem services and societal benefits with the DPSIR framework in a systems approach. Mar. Pollut. Bull. 2011, 62, 215-226. [CrossRef] [PubMed]

46. O'Higgins, T.; Lago, M.; Dewitt, T.H. Ecosystem-Based Management, Ecosystem Services and Aquatic Biodiversity; Springer Nature: Berlin/Heidelberg, Germany, 2020.

Publisher's Note: MDPI stays neutral with regard to jurisdictional claims in published maps and institutional affiliations.

(C) 2020 by the authors. Licensee MDPI, Basel, Switzerland. This article is an open access article distributed under the terms and conditions of the Creative Commons Attribution (CC BY) license (http://creativecommons.org/licenses/by/4.0/). 